OPEN ACCESS

Citation: Wong Sin Yeng et al. (2020) Studies on Potheae of Borneo II: Pedicellarum M. Hotta subsumed into Pothos L., and recognition of three new species. Webbia. Journal of Plant Taxonomy and Geography 75(1): 89-103. doi: 10.36253/jopt-7944

Received: January 29, 2020

Accepted: April 27, 2020

Published: June 30, 2020

Copyright: (c) 2020 Wong Sin Yeng, Jyloerica Joling, Joan T. Pereira, Alviana Damit, Peter C. Boyce, Alistair Hay. This is an open access, peerreviewed article published by Firenze University Press (http://www.fupress. com/webbia) and distributed under the terms of the Creative Commons Attribution License, which permits unrestricted use, distribution, and reproduction in any medium, provided the original author and source are credited.

Data Availability Statement: All relevant data are within the paper and its Supporting Information files.

Competing Interests: The Author(s) declare(s) no conflict of interest.

Funding: This is part of an ongoing research project funded by the Sarawak State Government Vote No. F07/NRGS/RIMC/2019.

Editor: Riccardo M. Baldini, University of Florence, Italy

\section{Studies on Potheae (Araceae) of Borneo II: Pedicellarum M.Hotta subsumed into Pothos L., and recognition of three new species}

\author{
Wong Sin Yeng ${ }^{1,2,3, *}$, Jyloerica Joling ${ }^{1}$, Joan T. Pereira 4 , Alviana \\ DAmit ${ }^{4}$, Peter C. Boyce ${ }^{3}$, Alistair HaY ${ }^{5,6}$ \\ ${ }^{1}$ Institute of Biodiversity and Environmental Conservation, Universiti Malaysia Sarawak \\ 94300 Kota Samarahan, Sarawak, Malaysia \\ ${ }^{2}$ Harvard University Herbaria, Cambridge, MA, USA \\ ${ }^{3}$ Department Biologie I, Systematische Botanik und Mykologie, Ludwig-Maximilians- \\ Universität München, München, Germany \\ ${ }^{4}$ Forest Research Centre, Sabah Forestry Department, P.O. Box 1407, 90715 Sandakan, \\ Sabah, Malaysia \\ ${ }^{5}$ Royal Botanic Gardens, Mrs Macquaries Road, Sydney 2000, Australia \\ ${ }^{6}$ Jardín Botánico de la Paz y Flora, Bitaco, Valle del Cauca, Colombia \\ ${ }^{*}$ Corresponding author. E-mail: sywong@unimas.my
}

\begin{abstract}
Pedicellarum is subsumed into Pothos as Pothos paiei. Four species, three taxonomically novel (Pothos degenerans, ecclesiae and P. fractiflexus) and one pre-existing (Pothos oliganthus) are discussed. The reproductive structures are reinterpreted and floral terminology used in this paper is in line with paving the way to interpreting the 'inflorescence' of Pothos, and indeed of all other aroids, as a unique array of structures that are neither flowers nor inflorescences as defined by current prevailing orthodoxy, but something of both.
\end{abstract}

Keywords: Borneo, Araceae, Potheae, Pedicellarum, Pothos.

\section{INTRODUCTION}

Pedicellarum paiei M.Hotta (Hotta 1976) is the sole described species of a genus of nomadic vines restricted to upper hill ridgetop kerangas in SW Sarawak. It was originally based on a single collection made close to the border between Sarawak and Kalimantan Barat in 1962, but later Nicolson (1984) drew attention to a previously overlooked second collection made $60 \mathrm{~km}$ further north about 35 years before. Pedicellarum has been considered unique amongst bisexual-floreted genera by possessing stipitate florets, with the top of the stipe swollen into a receptacle, an urceolate perigone of fused tepals, and (purportedly) introrse anther dehiscence. Grayum (1984: 634 ; 1992) remarked on a suite fertile and vegetative morphological similarities seemingly connecting Pedicellarum and Pothos species, and proposed a 
combination in Pothos although without effective publication (Grayum 1984: 634). Later, Grayum (1990: 670) revised his opinion and left the status of Pedicellarum unchanged. In fact, the earlier comparisons were based upon examination of material (P.J.Martin \& O.Ismawi $S$ 36660) mis-determined as Pedicellarum and then actually an undescribed species of Pothos.

Boyce and Hay (2001: 455) expanded on the similarities of Pedicellarum and Pothos species of the Goniurus supergroup (to which Hotta (1976) had also alluded relationship), noting the presence of a distinct receptacle, and fused tepals, and stating (as did Mayo et al. 1997) that anther dehiscence is latrorse, not introrse. Boyce \& Hay also clarified the identity of the P.J.Martin \& O.Ismawi S 36660 collection referred to by Grayum (1990), describing it as a new species - Pothos oliganthus P.C.Boyce \& A.Hay, and assigned an additional eight collections to Pedicellarum, extending the range of the genus south into Kalimantan Barat and north east to eastern Sabah.

While databasing specimens preparatory for the second author's Master's thesis it was necessary to reexamine the SAN duplicates of the two Sabah collections [Fidilis Krispinus SAN 104271 and Patrick Lassan SAN 107216] assigned to Pedicellarum paiei by Boyce and Hay (2000), and study for the first time a third, later, collection [Suzana S. SAN 154991]. All three collections, although agreeing with Pedicellarum paiei in having stipitate florets on a characteristically zig-zagging axis, lack the characteristic conspicuous floral receptacle, and have the fused tepals forming a shallow saucer; additionally the leaf blades are proportionately narrower and thicker textured than in P. paiei, and more or less straight, lacking the characteristic narrowed falcate terminus, while the mid-rib is abaxially much more pronounced, and drying much paler than the surrounding tissues. It was obvious that these collections, gathered over $800 \mathrm{~km}$ to the north east of the Type of Pedicellarum paiei, represented an undescribed species. Thus alerted, we examined the other duplicates assigned to Pedicellarum paiei, starting with three Alison Church collections [A.C. Church et al. 303, A.C. Church et al. 647and A.C. Church et al. 1014] from Kalimantan Barat. While appearing an excellent match for $P$. paiei by having stipitate florets with a receptacle and chartaceous leaf blades with a conspicuously narrowed falcate terminus, detailed examination, however, revealed that although the perigone lobes are fused below, the tips are evidently free. Examination of two collections previously unseen (P. Wilkie 94175 and Tuke P9 1102) from 75 $\mathrm{km}$ further south in Kalimantan Tengah confirmed the same morphologies. These five collections represented a third species distinct from both Pedicellarum paiei and from the Sabahan material.

Lastly, we turned attention to F.H. Endert 2942 from central Kalimantan Timur and a previously unseen collection (Bernard Lee Meng Hock S 45534) from Belaga, Kapit, Sarawak. Both have overall similarity to the Sabah specimens in possessing straight coriaceous leaf blades with an abaxially pronounced mid-rib drying paler than the surrounding tissues. Examination of the blooms, however, revealed differences in the straight, not zig-zagging spadix axis, almost sessile florets with largely, but not wholly, fused tepals, and blooms all depauperate, each with just two or three florets. Moreover, the blooms are produced in dense fascicles and (presumably) sequentially.

These examinations of material previously associated with Pedicellarum paiei revealed that there are five species involved, with three - one from western Kalimantan, one from central Borneo, and one from Sabah - representing undescribed taxa. Furthermore, taken as a whole these species cover a full range of the combinations of the 'characters' used to define Pedicellarum and those of Pothos such that maintenance of Pedicellarum as genus separate from Pothos is no longer justifiable. We therefore propose that Pedicellarum be merged with Pothos, including transferal of Pedicellarum paiei to Pothos, and that the three taxonomically novel species discussed above be described in Pothos.

Some floral terminology used in this paper differs intentionally from those of previous papers on Pothos and is intended to pave the way to interpreting the 'inflorescence' of Pothos, and indeed of all other aroids, as a unique array of structures that are neither flowers nor inflorescences as defined by current prevailing orthodoxy, but something of both. For the background to this conceptual change see Hay (2019), Hay and Mabberley (1991), Mabberley and Hay (1994). The 'pedicellarums' described in this paper are perhaps particularly germane as they present some of the inflorescences or blooms, and flowers or florets of Araceae that most resemble, at least to first glance, racemose inflorescences of more or less standard pedicellate trimerous monocotyledonous flowers of text books. Nevertheless, this is an illusion.

First, the spadices in these species, where phenology is known, are protogynous as entities, which is the standard behaviour of Araceae. So, despite their strikingly distant positioning, the florets do not behave as individual flowers but act in concert in a protogynous spadix. Second, again a standard feature of Araceae, there are no bracts subtending the florets, in spite of the resemblance of the spadix to a raceme in these species. The use of the term 'pedicel' for the stalks of the indi- 
vidual florets is prejudiced towards the conventional interpretation of the bloom as an inflorescence, despite the absence of subtending bracts and the phenological behaviour of the florets being subordinate to that of the spadix. We therefore use the more neutral (in this context) term 'stipe' and the corresponding adjective 'stipitate', rather than describing the florets as 'pedicellate'.

Another interesting aspect of the morphology of the florets of this group of species concerns the perigon. That of the sessile florets of Pothos oliganthus consists, conventionally for Pothos, of six free tepals, whereas that of the stipitate florets of Pothos paiei is a truncate cupule set on what appears to be an enlarged receptacle. This cupule is conventionally interpreted as a perigone of connate tepals, though, since there are no apparent tepal lobes at all, it might also be suggested that the tepals have been replaced by this cupular outgrowth of the receptacle. [Sadly, there are no floral developmental studies of this species group, for which it is extremely hard to find suitable quantities of fresh material]. Were one to view floret variation here as a morphocline, of the species newly described in this paper, Pothos degenerans, with sessile florets and a proximally cupular but distally lobed perigone sits nearer to P. oliganthus; Pothos ecclesiae, with stipitate florets and like $P$. degenerans a proximally cupular and distally lobed perigone is somewhat nearer $P$. paiei; while $P$. fractiflexus, with stipitate florets and an entirely cupular (but very shallow) perigone is nearer still to $P$. paiei.

We cannot speculate on the ecological function of these strangely stipitate, cupular-perigonate florets. However, it is noteworthy that they occur in perhaps the most extreme leptocaul of all aroids, a family mostly with relatively to absolutely massive pachycaul construction (except Lemnoideae, of course). Perhaps extreme leptocauly can sometimes lead to structural decanalisation.

Infrageneric classifications referred to follow Boyce and Hay (2001: 454-455). Geological occurrences in this paper are verified with Tate (2001).

\section{KEY TO POTHOS PAIEI AND ALLIES}

1 a. Leaf blades with a conspicuous narrowed falcate terminus; florets stipitate.

b. Leaf blades straight; florets sessile or stipitate 3

2 a. Tepals entirely connate into a cupular structure; receptacle conspicuous. SW Sarawak. Pothos paiei

b. Tepals basally connate, free from about half way from tip; receptacle inconspicuous. CW Kalimantan ........ Pothos ecclesiae
3 a. Florets stipitate, tepals connate into a shallow saucer. Sabah. Pothos fractiflexus

b. Florets sessile. 4

4 a. Spadix axis straight, not zig-zagging, with two or three florets; tepals largely but not wholly connate. C. Borneo ....

Pothos degenerans

b. Spadix zig-zagging, with up to seven florets; tepals free. SW Sarawak Pothos oliganthus

Pothos L., Sp. Pl. 968. 1753. Schott, Aroideae 21-25, t.31-56 (1856-1857) \& Gen. Aroid. 95 (1858) \& Prodr. Syst. Aroid. 558-575 (1860); Engl. in Engl., Pflanzenr. 21 (IV.23B): 21-44 (1905); Mayo et al., Genera of Araceae 98-99, pl.5, 108, a. (1997) [- Tapanava Adanson, Fam. 2: 470 (1763), nom. superfl.] - Type: Pothos scandens L.

Goniurus Presl, Epimel. Bot. 244 (1851, '1849'). - Type: Goniurus luzonensis ca Presl [= Pothos luzonensis (C. Presl) Schott].

[Potha O. Kuntze, Rev. Gen. 2: 742 (1891), orth. var.].

Pedicellarum M. Hotta, Acta Phytotax. Geobot. 27(3-4): 61 (1976); Nicolson, Aroideana 7(2): 56-57 (1984); Mayo et al., Genera of Araceae 100, pl.6, pl.108B (1997); Boyce \& Hay, Telopea 9(3): 254-258, Fig. 50 (2001), syn. nov. Type: Pedicellarum paiei M. Hotta.

Pothos degenerans S.Y.Wong, P.C.Boyce \& A.Hay, sp. nov.

Type: Malaysia. Sarawak, Kapit [7th Division], Belaga, Linau, Sungai Iban, 18 Nov 1989, Bernard Lee Meng Hock S 45534 (holotype SAR!; isotypes K!, L!, SAN!, MO, US!) (Figure 1).

\section{Diagnosis}

Pothos degenerans is most similar to Pothos fractiflexus by the straight coriaceous leaf blades with an abaxially pronounced mid-rib drying paler than the surrounding tissues. However, Pothos degenerans has up to 3 florets per spadix (vs 7 or more in $P$. fractiflexus), an almost straight or only very weakly (not strongly) zig-zagging spadix axis, sessile (vs stipitate) florets with a receptacle of partially (not wholly) fused tepals.

\section{Description}

Probably heterophyllous, root-climbing nomadic leptocaul vines. Adult shoot system not completely known 


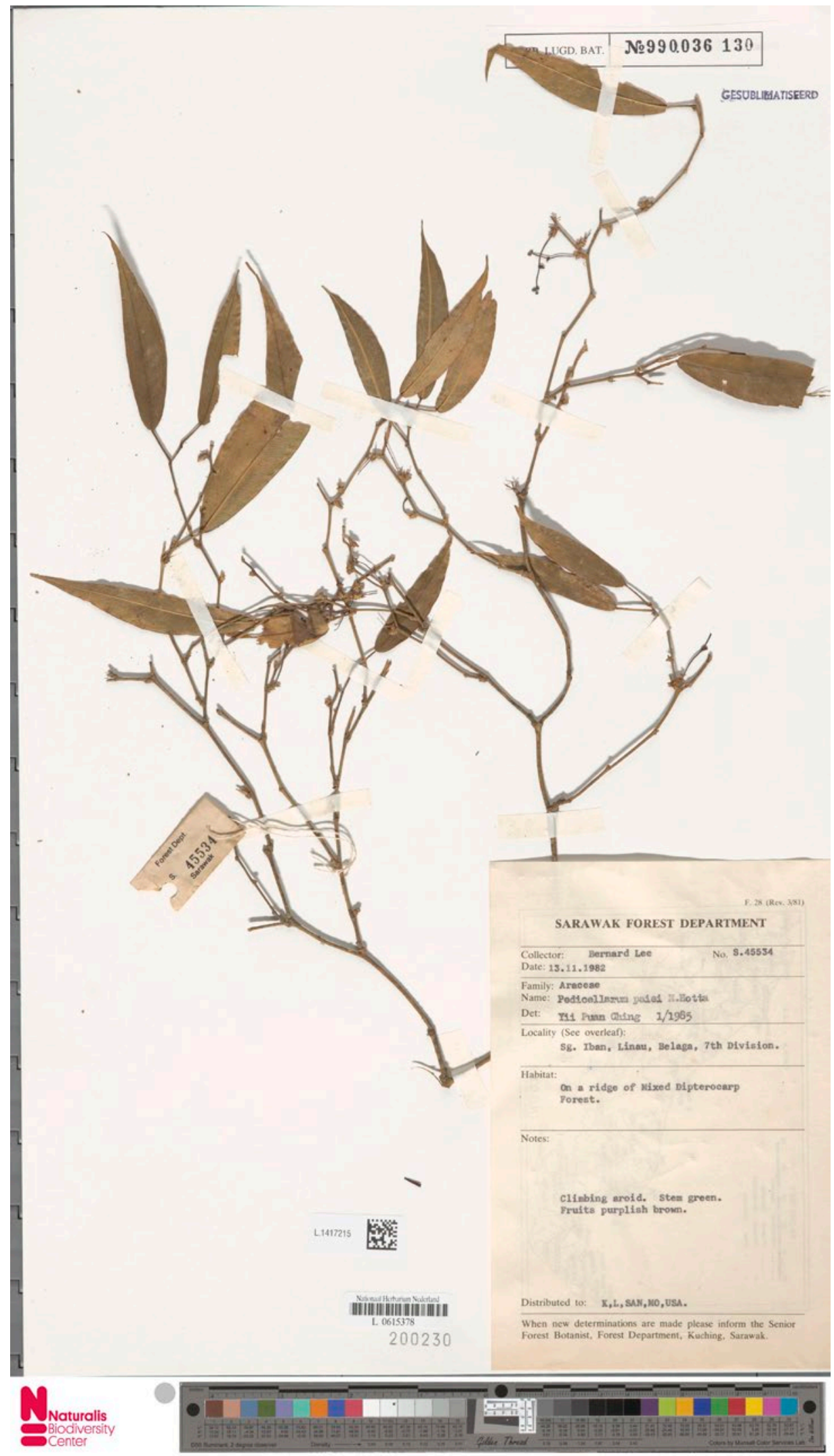

Figure 1. Pothos degenerans - Bernard Lee Meng Hock S 45534. Isotype [L]. 
but, in any case, differentiated into non-flowering orthotropic adherent stems, free lateral fertile stems, and much abbreviated cataphyll-encased (foliage-) leafless flowering shoots arising from below the petiole insertion; eocaul, seedling, and flagellate foraging shoots unknown. Leaves stiffly but thinly coriaceous, drying medium brown, abaxially somewhat paler with the prominent mid-rib markedly paler; petiole $1-2 \times 0.1-0.2 \mathrm{~cm}$, slender, very narrowly canaliculate, apex geniculate, sheath indistinct; blade 5-11 × 1.5-3 cm, narrowly elliptic, apex acute, apiculate, base subacute to obtuse; primary lateral veins arising at $60-70^{\circ}$, two intramarginal veins per side, 2-3 $\mathrm{mm}$ from blade margin, arising from just above base of the midrib, remaining \pm parallel to margin, terminating at the tip of the blade. Blooms in fascicles of up to ten per flowering shoot; peduncle $6-8 \times 1 \mathrm{~mm}$, very slender, straight, the bloom spreading, purplish brown. Spathe $4 \times 4 \mathrm{~mm}$, ovate, base rounded, amplexicaul on peduncle, cucullate-concave, apex briefly acuminate, purplish brown. Spadix stipitate; stipe $10 \times$ ca $0.9 \mathrm{~mm}$, terete, amounting to about $3 / 4$ of entire spadix; fertile portion $10 \times 1.5 \mathrm{~mm}$, slender cylindric, almost straight, purplish brown. Florets up to 3 per spadix, ca $2 \mathrm{~mm}$ diam., loosely clustered, sessile; tepals basally fused apically free; stamens six, free; filaments broader than the anthers; pistil oblong-cylindric, truncate, purplish brown. Infructescence, fruits and seeds unknown.

\section{Etymology}

From Latin degenerans, reduced, in allusion to the blooms, the smallest yet recorded for the genus, each with at most three florets.

\section{Distribution}

Central Borneo, known from two localities approximately $300 \mathrm{~km}$ apart.

\section{Ecology}

Lowland forested ridges and riverine forest, to about 200 $\mathrm{m}$ asl. The Kapit collection is from Eocene sedimentaries, the Kalimantan one from Cretaceous-Jurassic deepwater sediments.

\section{Notes}

The remarkably slender and diminutive blooms of Pothos degenerans are both easily overlooked and readily detached from specimens. Each flowering node has numerous denuded pedicels indicating blooms produced in fascicles, but it is not possible from the available specimens to determine if the blooms mature in a sequential series (as in all known Pothos producing fas- cicles of blooms), or if all the blooms in a fascicle reach anthesis simultaneously. The absence of any fruiting seems to favour the second scenario except that the large number of missing blooms indicated by the barren pedicels might have taken with them any developing fruits favouring the first scenario.

\section{Other specimen examined}

BORNEO: Indonesia. Kalimantan Tengah, Kutai Barat [West Koetai], No. 28, near Long Liah Leng, 200 m, 28 Aug 1925, F.H. Endert 2942 (AAH, BO, K, L).

\section{Pothos ecclesiae P.C.Boyce, S.Y.Wong \& A.Hay, sp. nov.}

Type: Indonesia, Kalimantan Barat, Sintang, $\mathrm{HPH}$ $\mathrm{km} \mathrm{69-73,} \mathrm{west} \mathrm{of} \mathrm{camp} \mathrm{off} \mathrm{main} \mathrm{(new)} \mathrm{logging} \mathrm{road,}$ cutting black and surrounding environs, 0 51'53.6”S $112^{\circ} 13$ '29.9”E, 150 m, 19 April 1994, A.C. Church et al. 1014 (holotype NY!; isotypes AAH!, BO, K!) (Figures 2 and 3).

\section{Diagnosis}

Pothos ecclesiae is most easily confounded with Pothos paiei in having a conspicuous receptacle, stipitate florets, and chartaceous leaf blades with a conspicuously narrowed falcate terminus. However, the free perigone lobes of Pothos ecclesiae are immediately diagnostic. The two species are also ecologically dissimilar, with $P$. ecclesiae occurring in lowland dipterocarp-dominated forest on red clay soils whereas $P$. paiei occurs on upper hill kerangas ridges.

\section{Description}

Probably heterophyllous, root-climbing nomadic leptocaul vines. Adult shoot system not completely known, from available material differentiated into non-flowering orthotropic adherent stems, free lateral fertile stems, and much abbreviated cataphyll-encased (foliage-) leafless flowering shoots arising from below the petiole insertion; eocaul, seedling, and flagellate foraging shoots unknown. Leaves chartaceous, drying dull pale brown; petiole $1-3 \times 0.1-0.2 \mathrm{~cm}$, slender, very narrowly canaliculate, apex geniculate, sheath indistinct, no sign of it clasping the stem in material available; blade 5-17 $\times$ $1.5-5 \mathrm{~cm}$, elliptic or ovate-elliptic, with one side unequal to the other, apex long-acuminate, markedly falcate, apiculate, base subacute to obtuse; primary lateral veins arising at $60-70^{\circ}, 2$ intramarginal veins per side, 2-15 $\mathrm{mm}$ from blade margin, arising from just above base of the midrib, remaining \pm parallel to margin, terminating at the tip of the blade. Blooms solitary to rarely paired; 


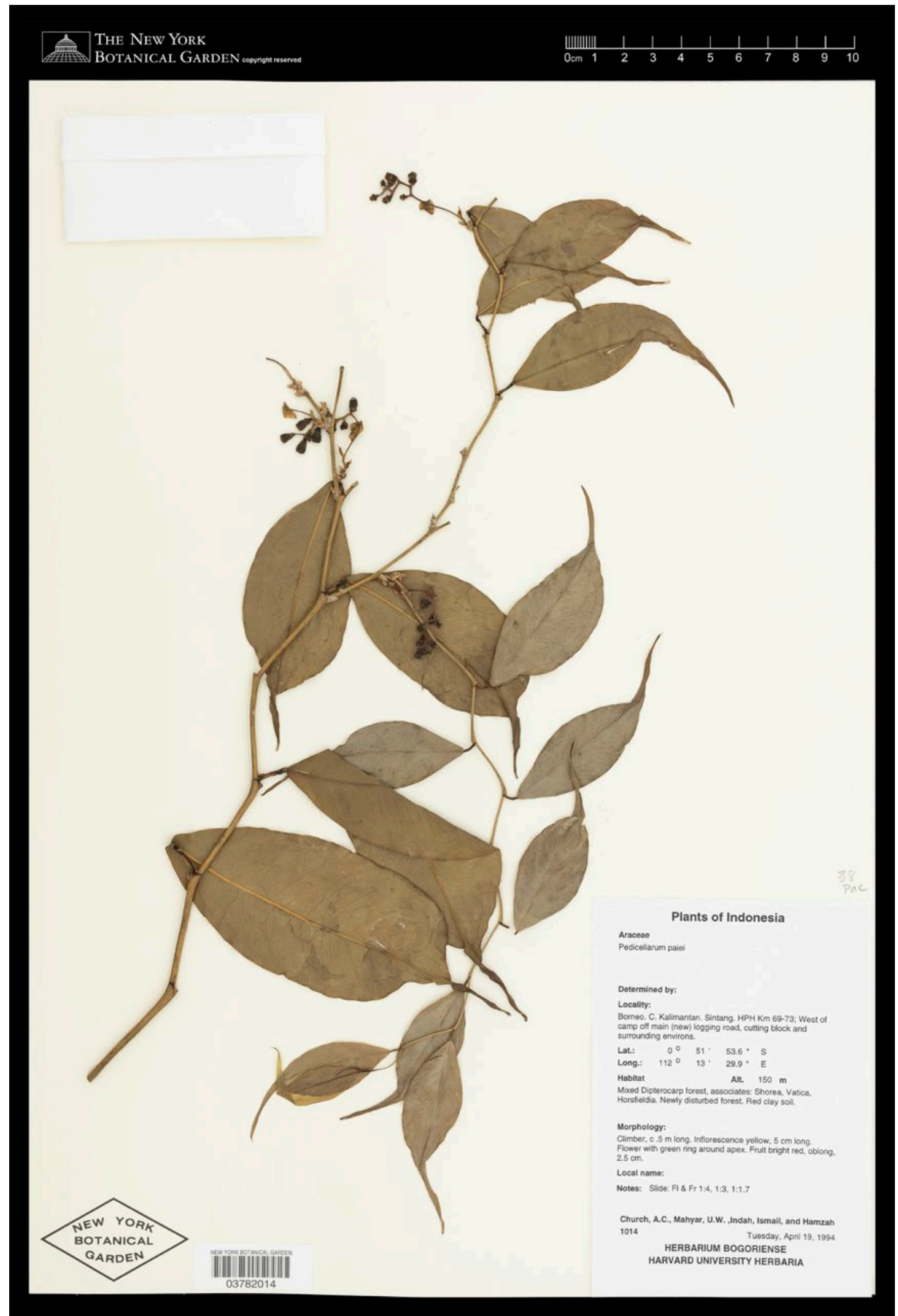

Figure 2. Pothos ecclesiae - A.C.Church et al. 1014. Holotype [NY]. 


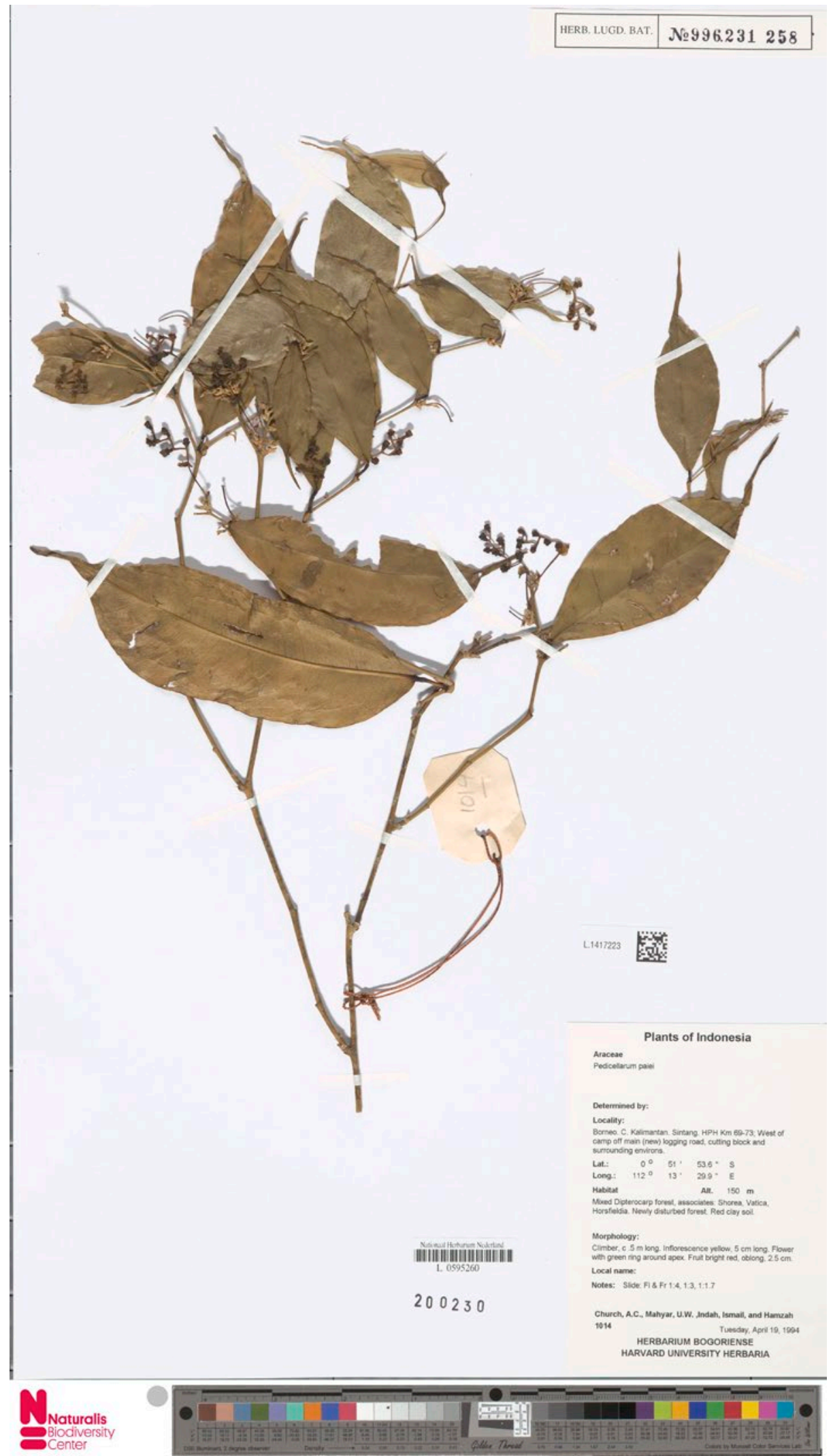

Figure 3. Pothos ecclesiae - A.C.Church et al. 1014. Isotype [L]. 
peduncle $6-8 \times$ ca $0.1 \mathrm{~mm}$, very slender, straight, the bloom held erect to spreading, greenish yellow. Spathe 4-6 $\times$ ca $4 \mathrm{~mm}$, ovate, base rounded, amplexicaule on peduncle, cucullate-concave, apex somewhat acuminate, yellow. Spadix stipitate; stipe $10-11 \times$ ca $0.9 \mathrm{~mm}$, terete; fertile portion $2-3 \times \mathrm{ca} 0.15 \mathrm{~cm}$, slender cylindric, prominently zig-zagging at each floret insertion, yellow. Florets five to eight per spadix, ca $2 \mathrm{~mm}$ diam., widely scattered, stipitate, with a receptacle; tepals six, fused to about half way; stamens six, free; filaments slightly broader than the anthers; pistil oblong-pyriform, truncate, yellow. Infructescence with rather few berries; fruit 6-13 $\times 4-6 \mathrm{~mm}$, elongate oblong-ellipsoid with a rounded apex, ripening glossy scarlet; seeds elongate-ellipsoid, $4-6 \times 3-4 \mathrm{~mm}$.

\section{Eponymy}

From Latin, ecclesiae, literally 'of the church', devised to commemorate Alison C. Church, collector of the Type material.

\section{Distribution}

SW Borneo.

\section{Ecology}

Lowland mixed old secondary dipterocarp forest on red clay soils, $150-315 \mathrm{~m}$ asl. The three Alison Church collections are from the pre-Carbonifeous Pinoh metamorphics of the Schwaner Range while P. Wilkie 94175 and Tuke P9 1002 are from Lower Cretaceous granites to the south.

\section{Notes}

Fig. 50 in Boyce \& Hay 2001: 557, depicting Pedicellarum paiei and cited as being a drawing of Church et al. 1014, was mislabelled. The plate was prepared from the Type material of Pedicellarum paiei. The notes accompanying A.C. Church et al. 303 state the fruit to be edible and sweet.

\section{Other specimens examined}

BORNEO: Kalimantan: Kalimantan Barat. Sintang, Bk. Baka National park, along bank of Sungai Ella, $600 \mathrm{~m}$ east of camp, $0^{\circ} 38^{\prime} \mathrm{S} 112^{\circ} 17^{\prime} \mathrm{E}, 315 \mathrm{~m}, 22$ October 1993, A.C. Church et al. 303 (AAH, BO, K, L); Bukit Baka National Park, $200 \mathrm{~m}$ from logging road between $\mathrm{km} 39$ and $\mathrm{km} \mathrm{40,} \mathrm{environs} \mathrm{bordering} \mathrm{national} \mathrm{park} \mathrm{and} \mathrm{SBK,}$ $0^{\circ} 37^{\prime} \mathrm{S} 112^{\circ} 15^{\prime} \mathrm{E}, 310 \mathrm{~m}, 9$ Nov 1993, A.C. Church et al. 647 (AAH, BO, L). Kalimantan Tengah. Kotawaringin Timur, Plot 11, $\mathrm{km} 92$ from Sangai (Sungai Mentaya), 1 29'S 112 31'E', 50 m, 14 Apr 1994, P. Wilkie 94175 (E, L);
Plot 9, km 92 from Sangai (Sungai Mentaya), 1 29'S 112 31'E', 50 m, 1994, Tuke P9 1002 (AAH, E, L).

Pothos fractiflexus J.Joling, Pereira \& A.Damit, sp. nov.

Type: Malaysia, Sabah. Interior Division, Nabawan, Syt. Benawood, Sg. Maadun, 15 May 1987, Fidilis Krispinus SAN 104271 (holotype SAN!) (Figures 4 and 5).

\section{Diagnosis}

Pothos fractiflexus is similar to Pothos paiei in having stipitate florets on a characteristically zig-zagging spadix axis but differs in the fused tepals forming a shallow saucer (vs florets with an enlarged floral receptacle and tepals fused into a cupular structure), leaf blades proportionately narrower and thicker textured, and more or less straight (vs leaf blades chartaceous with a characteristic narrowed falcate terminus), and with the midrib abaxially much more pronounced, and drying much paler than the surrounding tissues.

\section{Description}

Probably heterophyllous, root-climbing nomadic leptocaul vines. Adult shoot system not completely known, at least differentiated into non-flowering orthotropic adherent stems, free lateral fertile stems, and much abbreviated cataphyll-encased (foliage-) leafless flowering shoots arising from below the petiole insertion; eocaul, seedling, and flagellate foraging shoots unknown. Leaves stiffly coriaceous, drying medium brown, abaxially somewhat paler with the prominent mid-rib markedly paler; petiole $1-2 \times 0.1-0.2 \mathrm{~cm}$, slender, very narrowly canaliculate, apex geniculate, sheath very indistinct; blade 5-11 $\times 1.5-3 \mathrm{~cm}$, narrowly elliptic, apex acute, apiculate, base subacute to obtuse; primary lateral veins arising at $60-70^{\circ}$, two intramarginal veins per side, $2-3$ $\mathrm{mm}$ from blade margin, arising from just above base of the midrib, remaining \pm parallel to margin, terminating at the tip of the blade. Blooms solitary or paired; peduncle 6-8 $\times 1 \mathrm{~mm}$, very slender, straight, the bloom spreading, yellowish. Spathe $4 \times 4 \mathrm{~mm}$, ovate, base rounded, amplexicaule on peduncle, cucullate-concave, apex briefly acuminate, yellowish. Spadix stipitate; stipe $10 \times$ ca $0.9 \mathrm{~mm}$, terete; fertile portion $10 \times 1.5 \mathrm{~mm}$, slender cylindric, strongly zig-zagging, yellowish. Florets up to 7 per spadix, ca $2 \mathrm{~mm}$ diam., loosely clustered, sessile; tepals wholly? connate into a shallow saucer; stamens 6 , free; filaments broader than the anthers; pistil oblongcylindric, truncate, yellowish. Infructescence with rather few berries; fruit 6-13 $\times 4-6 \mathrm{~mm}$, elongate oblong-ellipsoid with a rounded apex, ripening glossy scarlet; seeds 


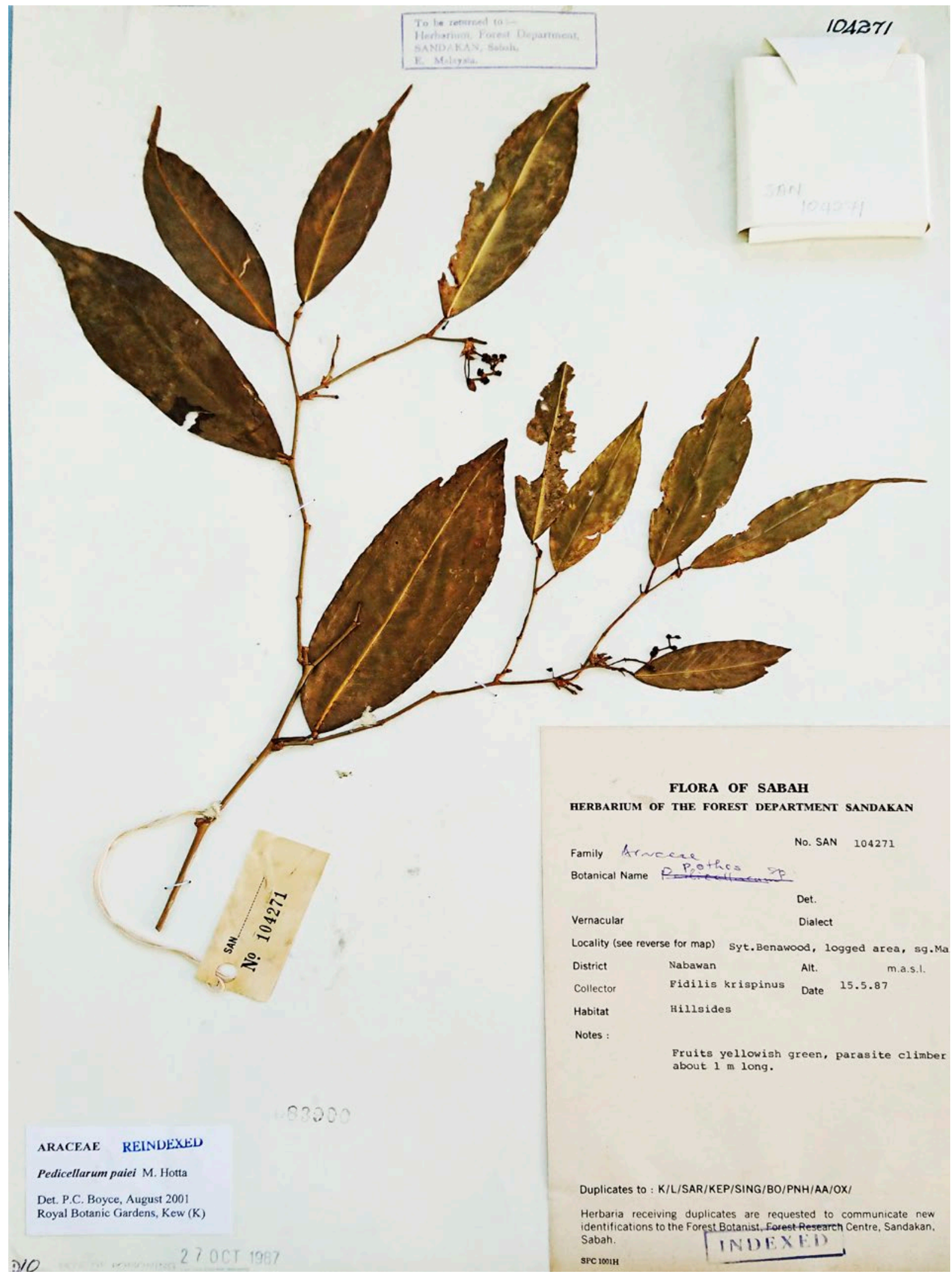

Figure 4. Pothos fractiflexus - Fidilis Krispinus SAN 104271. Isotype [SAN]. 
elongate-ellipsoid, 4-6 × 3-4 mm.

\section{Etymology}

From fractiflex - zig-zagging - used to describe the spadix axis.

\section{Distribution}

East Sabah.

\section{Ecology}

Forested hillsides on Neogene or Quaternary sediments between 300 and $500 \mathrm{~m}$ asl.

\section{Notes}

In general appearance very close to Pothos degenerans, but readily differentiated by stipitate florets and shallow saucer-like perigone.

\section{Other specimens examined}

BORNEO: Sabah: Sandakan Division. Ulu Sg. Pinangah, 17 Oct 1984, Patrick Lassan SAN 107216 (L, K, SAN); Interior Division. Sapulut, Nurod-Urod F.R., 4³5'10”N $116^{\circ} 54^{\prime 2} 7^{\prime} \mathrm{E}, 582 \mathrm{~m}$ asl, 14 Jun 2012, Suzana S. SAN 154991 (SAN).

Pothos oliganthus P.C.Boyce \& A.Hay, Telopea 9(3): 552. 2001

Type: Malaysia, Sarawak, Sri Aman Division [2nd Div.], 85th mile, Ulu Sg. Silantek Kiri, path from Gunung Silantek, 300 m, 26 Aug 1980, Ilias Paei S 42566 (holotype K!; isotypes AAH!, L!, MO!, SAN!, SAR!). (Figure 6).

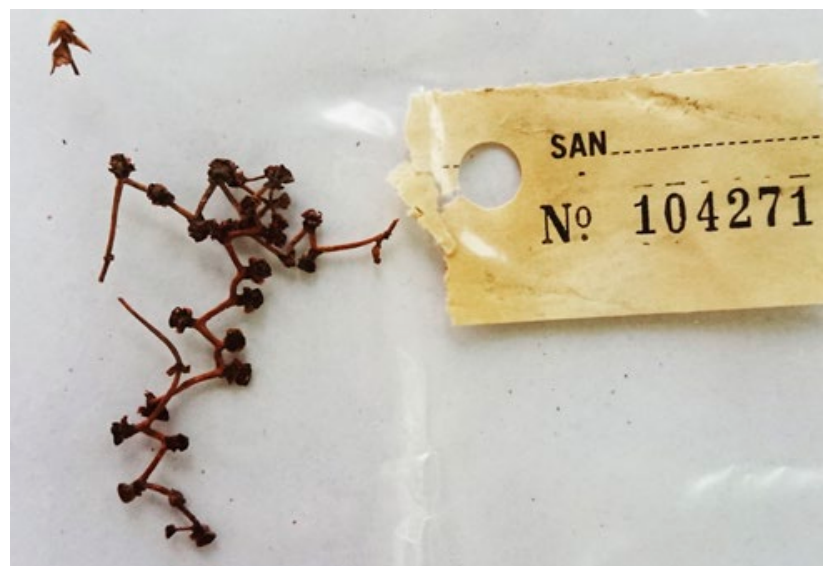

Figure 5. Pothos fractiflexus - Fidilis Krispinus SAN 104271. Isotype [SAN] - detail of the blooms.

\section{Description}

Probably heterophyllous, root-climbing nomadic leptocaul vines. Adult shoot system not completely known, at least differentiated into non-flowering orthotropic adherent stems, free lateral fertile stems, and much abbreviated cataphyll-encased (foliage-) leafless flowering shoots arising from below the petiole insertion; eocaul, seedling, and flagellate foraging shoots unknown. Leaves somewhat coriaceous, drying greenish brown; petiole 0.4-3 $\times 0.1-0.12 \mathrm{~cm}$, slender, very narrow-canaliculate, apex weakly geniculate, sheath distinct, prominent, erect, apically ligulate in young growth, ligule later disintegrating; blade 6-21 $\times 1-4.5 \mathrm{~cm}$, very narrowly to narrowly elliptic, oblique, weakly falcate, apex long-acuminate, apiculate, apicule later deciduous, base obtuse; primary lateral veins arising at $60-70^{\circ}$, two intramarginal veins per side, $2-8 \mathrm{~mm}$ from blade margin, arising from just above base of the midrib, remaining \pm parallel to margin, terminating at the tip of the blade. Bloom solitary, rarely several at different stages on a reiterating flowering shoot; peduncle $0.3-1.3 \times 0.05-0.1 \mathrm{~cm}$, very slender, pale green. Spathe ca $3 \times 2 \mathrm{~mm}$, oblong-ovate, cucullate, base rounded and amplexicaule on peduncle, apex acuminate, white. Spadix stipitate; stipe 1-7 mm long, terete; fertile portion $0.3-0.5 \mathrm{~cm}$, very slender-cylindric, white. Florets usually three, up to six per spadix, sessile, ca $1.5 \mathrm{~mm}$ diam., slightly scattered, with six free tepals and six stamens. Pistil squat oblong cylindric, truncate. Infructescence with few fruits; fruit (immature) $3-5 \times 2-3 \mathrm{~mm}$, obclavate ellipsoid; seeds not observed.

\section{Distribution}

Endemic to SW Sarawak.

\section{Habitat}

Mixed lowland to hill dipterocarp forest on slopes and ridges of Upper Cretaceous granite-derived yellow sandy clays, 300-540 m altitude.

\section{Notes}

Despite being earlier confounded with Pothos [Pedicellarum] paiei, $P$. oliganthus is readily differentiated by the stiffly leathery narrowly elliptic leaf blades, sessile florets, and free tepals. In overall appearance the narrow stiff leaf blades of Pothos oliganthus make it reminiscent of $P$. degenerans and $P$. fractiflexus and like $P$. degenerans, $P$. oliganthus has blooms with very few sessile florets.

\section{Other specimens examined}

BORNEO: Sarawak: Samarahan Division [1st/2nd Div. Boundary], [Simunjan], Gunung Buri, 75th mile, $540 \mathrm{~m}$, 


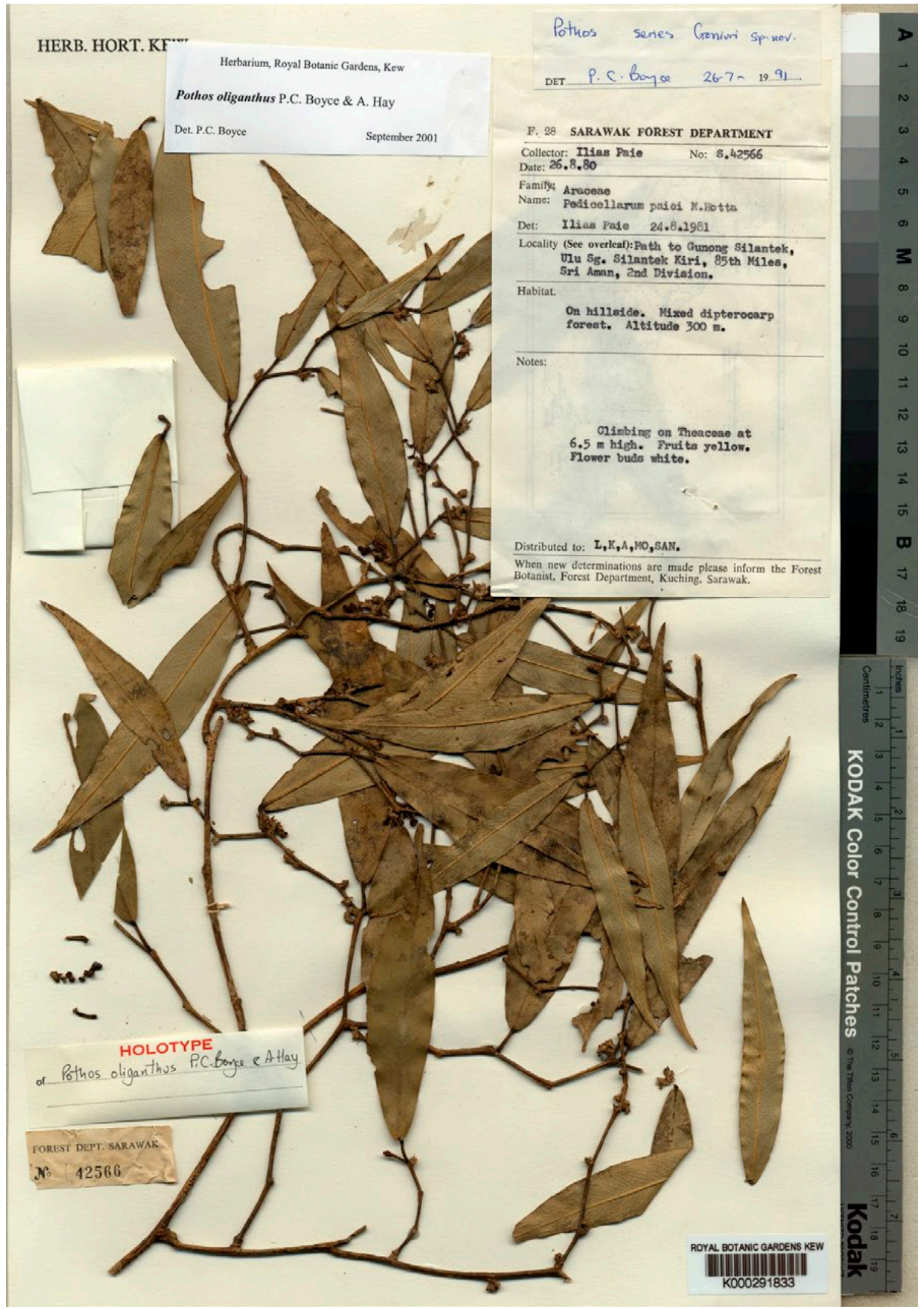

Figure 6. Pothos oliganthus - Ilias Paie S 42566. Holotype [K]. 
12 Sep 1975, P.J. Martin \& O. Ismawi S 36660 (K, KEP, L, MO, SAR, US); Samarahan Division [1st Division], [Simunjan], Gunung [Bukit] Buri, 440 m, 25 May 1981, Ilias Paie S 42082 (K, L, SAN, SAR, US).

Pothos paiei (M.Hotta) S.Y.Wong, A.Hay \& P.C.Boyce, comb. nov.

Basionym: Pedicellarum paiei M. Hotta, Acta Phytotax. Geobot. 27(3-4): 61-65 (1976); Nicolson, Aroideana 7(2): 56-57 (1984); Mayo et al., Genera of Araceae 100, pl. 6 \&108B (1997); Boyce and Hay, Telopea 9(3): 254-258, Fig. 50 (2001).

Type: Malaysia, Sarawak, Serian Division, [9th Div.], Gunung Penrissen, 914 m., 3 May 1962, Ilias Paie S 16354 (holotype KYO!; isotypes K!, L!, SING!). (Figures 7 and 8).

\section{Description}

Heterophyllous, root-climbing nomadic leptocaul vines. Adult shoot system differentiated into non-flowering orthotropic adherent stems, free lateral fertile stems, and much abbreviated cataphyll-encased (foliage-) leafless flowering shoots arising from below the petiole insertion; eocaul and flagellate foraging stems resembling slender green wire, furnished with tiny distantly-spaced acute bracts; seedling and newly climbing foraging stems shingling with leaf blades ovate with short rounded basal lobes separated by a very narrow sinus and a briefly cuspidate tip, stems somewhat flattened and longitudinally sulcate on the narrow sides. Leaves chartaceous, rather bright semi-glossy mid-green, scarcely paler abaxially; petiole $1-7 \times 0.1-0.3 \mathrm{~cm}$, slender, very narrowly canaliculate, apex geniculate, sheathing until just below apical geniculum, sheath wings very narrow, initially clasping the stems, later spreading, extended into a brief narrow blunt ligule; blade 5-16 $\times 1.5-5 \mathrm{~cm}$, elliptic or ovate-elliptic, usually with one side unequal to the other, apex long-acuminate, markedly falcate, apiculate, apicule later deciduous, base subacute to obtuse; primary lateral veins arising at $60-70^{\circ}$, two intramarginal veins per side, $2-6 \mathrm{~mm}$ from blade margin, arising from just above base of the midrib, remaining \pm parallel to margin, terminating at the tip of the blade. Blooms solitary to rarely paired; peduncle $6-8 \times$ ca $0.1 \mathrm{~mm}$, very slender, straight, the bloom held erect to spreading, greenish yellow. Spathe $4-6 \times$ ca $4 \mathrm{~mm}$, ovate, base rounded, amplexicaul on peduncle, somewhat cucullate-concave, apex briefly acuminate, greenish yellow. Spadix stipitate; stipe $3-4 \times$ ca $0.9 \mathrm{~mm}$, terete; fertile portion $2-3.5 \times$ ca
$0.15 \mathrm{~cm}$, slender cylindric, prominently zig-zagging at each floret insertion, greenish yellow. Florets five to eleven per spadix, ca $2 \mathrm{~mm}$ diam., widely scattered, briefly stipitate, arranged in two rather irregular rows along the spadix; receptacle prominent; tepals 6 , fused into an urceolate cup; stamens six, free; filaments broader than the anthers. Infructescence with few berries; fruit 6-13 $\times$ 4-6 $\mathrm{mm}$, elongate oblong-ellipsoid with a truncate apex, ripening glossy scarlet; seeds elongate-ellipsoid, 4-6 $\times$ 3-4 mm.

\section{Distribution}

SW Sarawak.

\section{Habitat}

Primary to disturbed secondary upper hill ridge kerangas forest between 600-950 m altitude.

\section{Other specimens examined}

BORNEO: Sarawak: Kuching Division. [1st Div.], proposed Matang National Park, Ulu Sg. Rayu, 27 Apr 1987, Bernard Lee Meng Hock S 54080 (K, KEP, L, SAN, SAR, US); Mount Matang, $700 \mathrm{~m}$ asl, 1927-1928, 'Native collector' 5178 Collected through the Sarawak Museum for the California Botanic Garden (NY).

\section{ACKNOWLEDGEMENTS}

Fieldwork was most recently under Sarawak Forestry Department Permission to Conduct Research on Biological Resources - Permit No. (67) JHS/NCCD/600-7/2/107/ Jld.2 and Park Permit No WL33/2019. The collaboration and support of the Sarawak Forestry Department and the Sarawak Biodiversity Centre are gratefully acknowledged. The last author extends his thanks to Tan Sri Datuk Amar Leonard Linggi Anak Jugah and Malesiana Tropicals Sdn Bhd for continued support and encouragement.

\section{REFERENCES}

Boyce PC \& Hay A. 2001. A taxonomic revision of Araceae tribe Potheae (Pothos, Pothoidium and Pedicellarum) for Malesia, Australia and the tropical Western Pacific. Telopea 9(3): 449-457.

Grayum MH. 1984. Palynology and phylogeny of the Araceae. Ph.D. Dissertation. Univ. Massachusetts, Amherst, Massachusetts.

Grayum MH. 1990. Evolution and phylogeny of the Araceae. Annals of the Missouri Botanical Garden 77(4): 628-697. 


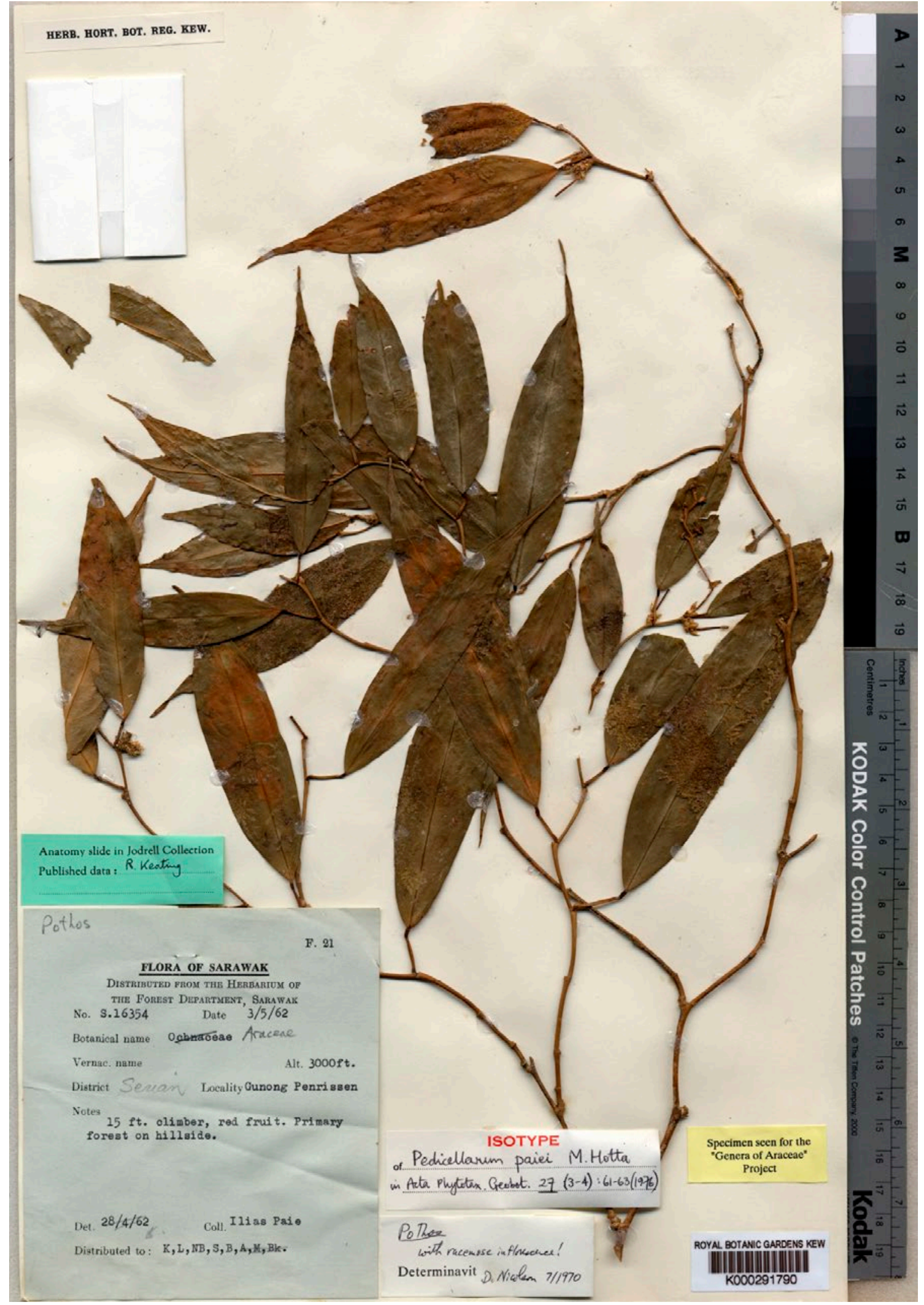

Figure 7. Pothos paiei - Ilias Paie S 16354. Holotype [K]. 

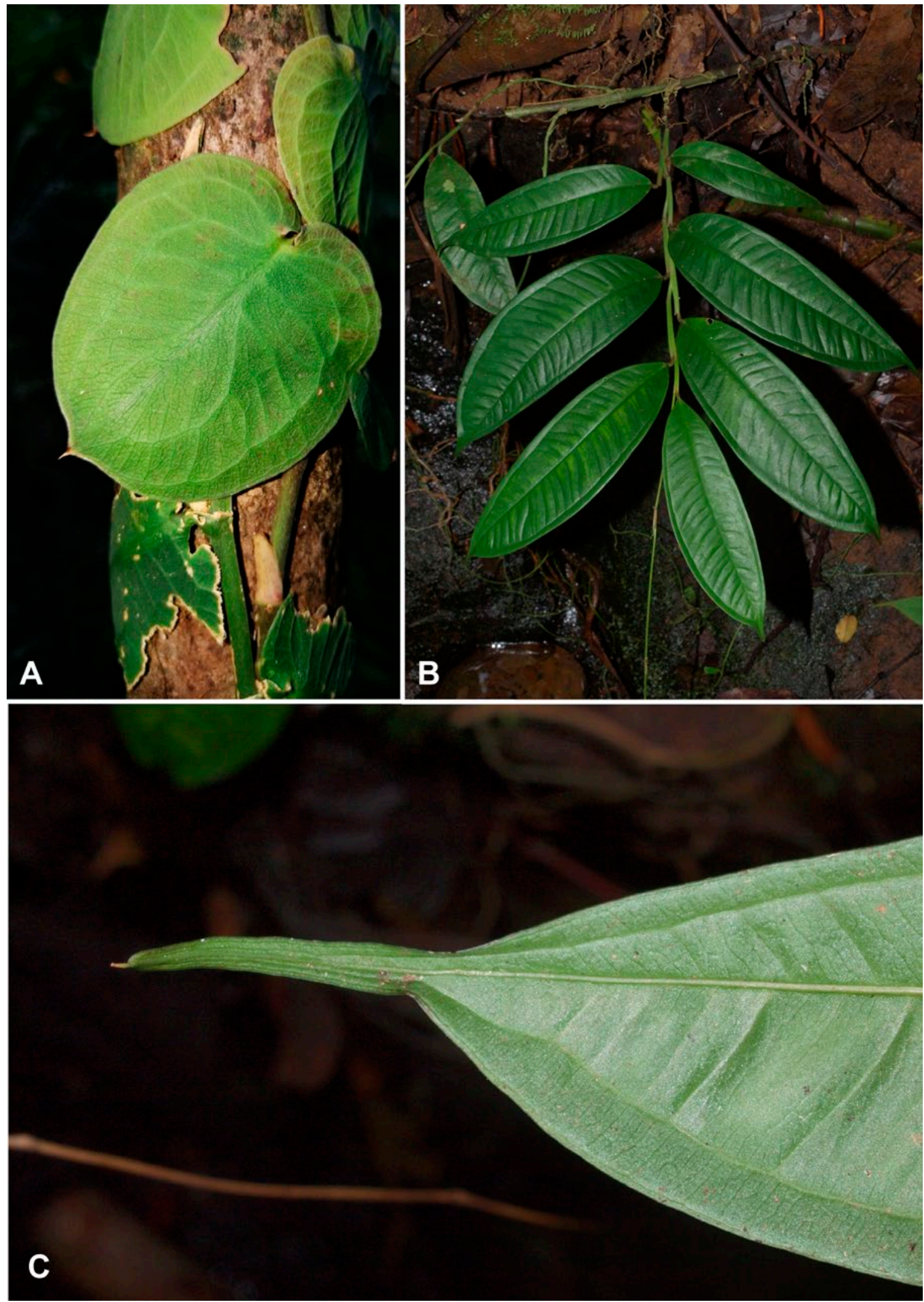

Figure 8. Pothos paiei in habitat in the general vicinity of the type location. All from AR-4974. 
Hay A. 2019. Durianology, discovery, and saltation: the evolution of aroids. Gardens' Bulletin Singapore 71(Suppl. 2): 257-313.

Hay A \& Mabberley DJ. 1991. 'Transference of function' and the origin of aroids: their significance in early angiosperm evolution. Botanische Jahrbücher fur Systematik, Pflanzengeschichte und Pflanzengeographie. 113: 330-428.

Hotta M. 1976. Notes on Bornean Plants III: Pedicellarum and Heteroaridarum, two new genera of the aroids. Acta Phytotaxonomica et Geobotanica 27(34): 61-65.

Mabberley DJ \& Hay A. 1994. Homoeosis, canalization, decanalization, 'characters' and angiosperm origins. Edinburgh Journal of Botany. 51: 117-126.

Mayo SJ, Bogner J \& Boyce PC. 1997. The Genera of Araceae. Royal Botanic Gardens, Kew xi +370 pp. Moffett MW. 2000. What's "up"? A critical look at the basic terms of canopy biology. Biotropica 32(4a): 569-596.

Nicolson DH. 1984. A second collection of Pedicellarum (Araceae) Aroideana 7(2): 56-57.

Tate RB. 2001. The geology of Borneo island CDROM. Kuala Lumpur: Persatuan Geologi Malaysia / Geological Society of Malaysia.

Zotz G. 2013. 'Hemiepiphyte': a confusing term and its history. Annals of Botany. 111(6): 1015-1020. 